\title{
Positive Behavioral Interventions and Supports vs. Corporal Punishment: A Literature Review
}

\author{
Jon O. Downs \\ Louisiana State University, United States of America
}

\begin{abstract}
The following literature review provides information about School-wide Positive Behavioral Interventions and Supports (PBIS) initiatives at the elementary, middle, and high school building levels. The review also explains the importance teacher morale and overall school climate has on a student's education. A second component of this literature review focuses on corporal punishment in schools and how the use of this behavior discipline can serve as a detriment to students and their education process. The intentions and outcomes of this literature review are to educate and inform the reader of two behavioral interventions and the successes and lasting effects of those interventions. First, we will begin with Positive Behavioral Interventions and Supports.
\end{abstract}

\section{Introduction}

In a school, the state of teacher morale can have an important impact on student morale and overall climate of the entire school community. Teacher morale directly correlates to the quality of lessons presented to students, as well as the student's academic success, the student's attitude and mind-set toward learning, and the student's overall behavior and discipline [14]. In order to improve teacher morale, the overall school climate needs to be examined, analyzed, and improved using data-based methods. The goal of school climate improvement is to create a sustainable positive school climate for both the physical and psychological aspects of the school. When a positive school climate is established and sustained over a long period of time the following occurs: Transformation and improvement in curriculum, improvement of teaching and knowledge delivery, improvement of teacher evaluation results, and improvement in the area of student assessments [1]. These four improvement points are what the vast majority of educational professionals strive for each and every day.

\section{Morale}

There has been a steady decline in teacher morale in the Lafayette Parish School System in Louisiana.
At the start of the 2013-14 school year KATC News Channel reported on multiple occasions that teacher retirement and resignations are at the highest they have ever been in Lafayette Parish [2]. KATC went on to state the retirements and resignations of teachers in 2012-2013 were twice as high as in 20102011. They also stated that their research indicated the majority of the retirements and resignations are due to low morale and increasingly difficult teaching situations in the school system brought on by the new Compass teacher evaluation system. The news report also found similar results in Vermillion parish as well as at the state level. The decline in morale has resulted in many teachers either becoming complacent and apathetic in the classroom or leaving the teaching profession altogether.

Some of the contributing factors to teachers' low morale are undisciplined learners, heavy workloads, violence in schools, lack of parental and administrative support, lack of societal appreciation, and an over emphasis on teacher evaluation results, and an over emphasis on student standardized assessment results. It is of the utmost importance that school leaders, teachers, students, parents, and communities understand the importance of a positive school climate and how much a positive school climate ties into student and school achievement.

\section{School Climate}

School climate is defined as the quality and character of school life and encompasses the entire school community. The following information is from the National School Climate Center website:

School climate is based on patterns of students', parents' and school personnel's experience of school life and reflects norms, goals, values, interpersonal relationships, teaching and learning practices, and organizational structures. A sustainable, positive school climate fosters youth development and learning necessary for a productive, contributing and satisfying life in a democratic society. The National School Climate Center goes on to state that the following school traits are indicative of a positive and sustainable school climate: 
- Norms, values and expectations that support people feeling socially, emotionally and physically safe.

- People are engaged and respected.

- Students, families and educators work together to develop, live and contribute to a shared school vision.

- Educators model and nurture attitudes that emphasize the benefits and satisfaction gained from learning.

- Each person contributes to the operations of the school and the care of the physical environment.

The emergence of school climate and its impact on morale and overall school achievement has been taking place for several decades. Educators have long recognized the relationship between school climate and student achievement. According to Moos and Insel, in the 1970s, school climate was defined as the relationship of a person's environment and a person within the social and physical parts of the environment. This relationship is defined with three dimensions, which are interpersonal relationships, goal orientation with personal growth, and system maintenance with system change. The opinion of Moos and Insel also accounted for the need of caring relationships among teachers and educational leaders as positive role models, the need to establish high and reasonable expectations for student success, and an importance on positive reinforcement by way of rewarding positive behavior [13].

In the 1980s school climate was largely viewed from a community perspective, and the opinion was that the entire school community is more important than any individual within that community. Bryk and Driscoll believed that schools that stressed the importance of school community had higher student attendance rates, higher school-wide morale, and improved student achievement. It was also thought that teachers who took responsibility for student learning as well as professional development were more apparent in schools that were more community driven [3].

In the 1990s school climate was commonly associated with the phrase "academic press." Academic press simply means the amount or degree the school community, as a whole, practices and stresses the importance of academic success and consistency as well as its alignment with school values. All of this together is believed to improve and elevate standards for student performance.

As it stands now in the 21st century, educators and researchers have come to a general idea of the definition of school climate. This definition focuses on four major areas. The four areas are physical safety, relationships between individuals within the school environment who belong to the school community, teaching and learning methods, and the physical environment of the school and its surroundings [4].

\subsection{School Climate Research}

As previously mentioned, there is an abundance of research on the topic of school climate and Positive Behavior Interventions and Support. Schools with a substandard level of school climate do not allow teachers, support staff, and school leaders to act as positive role models for students. (Collaborative for Academic, Social, and Emotional Learning (CASEL), 2008). Wynn, Carboni, and Patall researched schools with negative school climates. Their findings suggested that schools with a negative school climate had a higher number of teacher absences as well as a higher percentage of teacher turnovers [17]. Similarly, researcher Megan Tschannen-Moran found that schools which were leader-centered and followed the rules to the fullest extent contained teachers who were more apathetic and very seldom went above and beyond the call of duty. This type of leadership also created distrust between the teachers and their school leaders [21].

Murray looked at the importance of new teachers creating successful relationships with other adults within the school community. These relationships formed a solid network for the new teacher and added to the longevity of the teacher's career. Adult employees within the school served as the model by which the students behaved [15].

Expanding on the thoughts of Murray, Ninan argues that children learn by the examples which are set by the adults in the school setting. The school environment is set by the teachers and other adults at the school. Therefore if the teachers have an elevated morale and a positive teacher climate is present then the students will are likely $t$ have elevated morale. This goes both ways however. If the teachers have poor morale and a negative school climate is present then the students will are more likely to have poor morale. [16] Whether consciously or subconsciously, the way teachers treat one another is engrained in students. Students are with teachers for the same amount of time, if not more, than they are with their parents. Due to this fact the onus is on the teachers to possess and display high moral and ethical character which will, in turn, trickle down to the student population. This, in effect, will create a more positive and sustainable school climate. It truly takes a village to raise a child and all teachers are an important member of the village and share the responsibility to take part in each child's upbringing. One implication of the aforementioned research is that teachers are not very likely to go the extra mile if their morale is low and if they work in a negative school climate. The other side of the coin shows how positive school climate and elevated morale can have a positive impact on students and achievement. 
Research has shown when teachers are more dedicated to their students, and go beyond their basic job expectations, there is a positive relationship created between the teacher and the student's academic success [21].

\section{Making a good school environment}

The significance of teachers serving as positive role models for students cannot be over-stated. Sandberg argued the extreme importance of schools creating entire school environments which exemplified high moral and ethical character. Sandberg takes a holistic approach on school climate improvement. She suggests that instead of only teaching character building lessons in the classroom it is also important that adults in the school community be constantly diligent and serve as good examples for students within the school community [19].

Despite the abundance of research available on the topic of the importance of school climate and school morale, there are still skeptics among some educational leaders, in particular at the state and federal government levels. Due to the amount of emphasis put on high-stakes testing by the federal government, our education system has become a testachievement driven system. Many educational researchers disagree with this type of measurement and feel that a more holistic approach is necessary to properly educate students. Due to the high emphasis on test performance, school climate concerns are often put on the back burner.

As time goes on and more research becomes available, increased attention to school climate will occur. School building-level leaders and teachers need to continue implementing a School-Wide Positive Behavior Interventions and Support system in order to keep school community morale high as well as promote a positive school climate. School community members need to put trust into the School-Wide Positive Behavior Interventions and Support system and use it to the fullest extent. If this system is utilized properly, the results will speak for themselves.

\subsection{Corporal Punishment}

Next we will take a look at corporal punishment. Corporal punishment has been used since colonial times in the United States. Within the past couple of decades, there has been a growing movement to ban this practice. The movement not only consists of parents but teachers, school administrators, and local, state, and national legislators. The advent of corporal punishment in the United States can be linked back to the colonization of the United States, however there have been many changes in the practice of the behavior discipline since colonial times. Garrison stated that the general consensus during the colonial period was that children were possessed by the devil and the only way for the devil to leave was by using physical force on the child [9]. There is evidence corporal punishment was used in schools prior to colonial times as well. Between the years 1000 and 1500, primary schools, secondary schools, and universities used some form of corporal punishment. The medieval era of education relied heavily upon corporal punishment. Parsons stated the following regarding the importance put on corporal punishment during medieval times: "in the eyes of medieval teachers and writers, physical correction was an intrinsic component of all instruction. Thus in his Dictionarius (c.1200), a vocabulary for students learning Latin, the grammarian John of Garland casually inserts 'the cane' among the 'necessary instruments for clerks', along with 'quills, a writing slate, a seat." [22]. This statement describes how education and corporal punishment went hand in hand and also how one did not seem to exist without the other.

Although corporal punishment was heavily used in medieval times there was some backlash and controversy associated with the discipline practice. Similar to today, medieval teachers were somewhat reluctant to use corporal punishment as a means of discipline. As stated by Parsons "the potential problems of beating were also recognized. Educators often showed a desire to confine it to clear channels, to ensure that its exercise was at every step governed by reason." [22]. This is simply describing that the medieval educators wanted to follow the rules exactly and not abuse the use of corporal punishment. In reference to abuse of corporal punishment, Parsons also went on to say "These limits also seem to have been accepted across medieval culture. Not only would pupils simply abscond if they felt their masters were unduly cruel, but medieval authorities often put their weight behind their objections to corporal punishment. There are records of teachers being successfully prosecuted for excessively beating pupils at Bristol and London, and at the French commune of SommeVesle." [22]. Similar to current issues and controversy surrounding corporal punishment in our schools, we see comparable controversies up to 1,000 years ago during medieval times.

Corporal punishment has been practiced in schools for over 1,000 years and is probably as old as humanity. In some cultures it is almost as inherent as customary as holiday celebrations and religious ceremonies, meaning it is culturally instinctual, identifiable, and fully accepted.

How do we move away from corporal punishment and use other means of discipline for our students? The following review of articles will serve as a starting point in answering this question. The articles contain relevant data, expert opinions, and 
first-hand accounts arguing for the removal of the practice of corporal punishment in our nation's schools.

What is the purpose of corporal punishment and why do we still use this behavior intervention? Dupper et al found that corporal punishment was used for three main reasons: 1) to produce people that would conform to accepted societal norms; 2) to "beat out the obstinacy" that was viewed as a syndrome of original sin, and 3) to ensure that learning occurs. Notice the third reason given is "to ensure that learning occurs." Students are in school to be educated and to learn: this is the number one priority. Some will say the number one priority is child safety, and yes we would agree with that but would also say that child safety is an understood priority and goes without saying. As we end our digression, please remember throughout this literature review that the number one job of an educator is simply to educate.[7]

\subsection{Corporal Punishment Research}

Dupper went on to suggest that the Bible played a major role in the reliance of corporal punishment during the 1700s. Dupper also cites the literal interpretation of Proverb 23:13-14, 'Do not withhold discipline from a child; if you punish him with the rod, he will not die. Punish him with the rod and save his soul from death'. Dupper et al. stated "the 18th century marked the first documented law regarding corporal punishment in schools." "In loco parentis", meaning "in position or place of parent", is the legal doctrine in which teachers and other school officials assume the parental rights of a minor [7]. This doctrine allowed teachers to used corporal punishment on their students in the absence of the parent. In other words, when the parent is not around, the teacher assumes the right to discipline the child exactly as the parent does. Garrison states courts consistently rule that parents were allowed "to administer such reasonable and timely punishment as may be necessary to correct faults in their growing children", and consequently teachers were given the right to correct faults in their students as well.

In Ingraham v. Wright the United States Supreme Court rejected the argument that corporal punishment in schools violates the Eighth Amendment's prohibition against cruel and unusual punishment, ruling that the Eighth Amendment simply does not apply in the school environment. The Court also ruled that school administrators are not required to give students a due process hearing prior to administering corporal punishment. [12]

The previous paragraphs reviewed some historical information regarding corporal punishment in schools and the use of it throughout history. Now we will take a look at current issues, research, and expert opinions on corporal punishment in schools.
The following is a definition of corporal punishment defined by Donald E. Greydanus. Greydanus is an expert in the field of violence and its effect on children and adolescents and has more than 35 years of experience. $\mathrm{He}$ is a professor of pediatrics and human development at Michigan State University and serves as the pediatrics program director at the Michigan State University Center for Medical Studies. He defines corporal punishment as the following:

Corporal punishment refers to intentional application of physical pain as a method of behavior change. It includes a wide variety of methods such as hitting, slapping, spanking, punching, kicking, pinching, shaking, shoving, choking, use of various objects (i.e., wooden paddles, belts, sticks, pins, or others), painful body postures (such as placing in closed spaces), use of electric shock, use of excessive exercise drills, or prevention of urine or stool elimination. The majority of children have experienced physical punishment by the time they reach adolescence. Corporal punishment in schools does not refer to the occasional need of a school official to restrain a dangerous student or use physical force as a means of protecting members of the school community subject to imminent danger [11].

The definition provided by Greydanus covers a wide range of physical punishment that many people in the education system may not associate with corporal punishment. For instance, how often does a coach push a student athlete to do more than their body is equipped to handle? This type of coaching happens all of the time. The correlation of corporal punishment to such things as excessive exercise drills, prevention of urine or stool elimination, or placing in closed spaces can increase the probability of breaking corporal punishment laws within the states and school districts. It is important that school districts understand the broad range of discipline techniques corporal punishment is identified with.

The use of corporal punishment in schools is more prevalent today than people may realize. According to Dr. Greydanus, "school officials, including teachers, administered corporal punishment to 223,190 school children across the nation during the 2006-2007 school year." He goes on to say "During this same period, the top ten states for students being hit were, in order of highest to lowest frequency: Mississippi, Arkansas, Alabama, Oklahoma, Louisiana, Tennessee, Oklahoma, Texas, Georgia, Missouri, and Florida.". This is an alarming amount of corporal punishment incidents. Many of the 223,190 school children who received corporal punishment during the 2006-2007 school year in the United States received it multiple times. According to Greydanus "Experts note that there are about 1.5 million reported cases of physical punishment in school each year, but calculate the actual number to 
be at least 2-3 million.". This is disturbing and seems to be excessive. There is also some other data Greydanus mentions concerning the location of corporal punishment, rural areas versus urban areas, a student race and the role their race plays in the frequency of corporal punishment incidents, as well as the frequency of corporal punishment in a selected group of states. Greydanus writes the following:

Youth who attend rural southern schools and who are male or who are African-American are more likely to be victims of corporal punishment.3,8 In fact, according to data from the US Department of Education's Office of Civil Rights, African American students comprise $17 \%$ of all public school students in the U.S., but are $36 \%$ of those who are victims of corporal punishment; this is more than twice the rate of white students. Looking at data from only the 13 states that paddle more than 1,000 per year, AfricanAmerican students make up 24.8 percent of the student population but 35.9 percent of those paddled. Additionally, almost $40 \%$ of all the cases of corporal punishment occur in just two states: Texas and Mississippi; also, if one adds Arkansas, Alabama, and Georgia, these five states account for almost three quarters of all the children receiving corporal punishment in schools [11].

After reading this data we cannot help but ask our original question of what is the purpose of corporal punishment and why do we still use this behavior intervention? With only the data Greydanus provided, solid arguments can be made for the immediate removal of corporal punishment practices in our nation's schools. Corporal punishment is wrong on many levels but the most disconcerting part of corporal punishment is that it is a violation of basic human rights. Corporal punishment is a human rights issue at its core; this is why it is such a disturbing practice. What is also disturbing is how divided citizens of United States are when it comes to their opinion on corporal punishment.

\subsection{Statistics of Corporal Punishment}

According to an ABC News article and poll by Julia Crandall most people in the United States approve of spanking kids and most people feel that corporal punishment is an acceptable practice. Keep in mind these majorities who are in favor of spanking children are referring to spanking children at home, not in schools. The article does go on to state that a majority of people polled did not feel that corporal punishment should be allowed in schools. Although this article and the polls taken along with this article were done in 2002 , it still gives us a glimpse as to what Americans' feelings are about the use of corporal punishment. We can hope that some of the opinions have changed since this poll was given. Hopefully a change has come with the advent of new generations of families, teachers, school administrators, and legislators. The following is more detail found in the article by Crandall: "Sixtyfive percent of Americans approve of spanking children, a rate that has been steady since 1990. But just 26 percent say grade-school teachers should be allowed to spank kids at school; 72 percent say it shouldn't be permitted, including eight in 10 parents of grade-schoolers.

Indeed, even among adults who spank their own child, 67 percent say grade-school teachers should not be permitted to spank children at school." [6]. This poll serves as proof, albeit from 2002, that the majority of Americans do not agree with corporal punishment in schools. They feel that it should be taken care of within the home by a child's parent.

Crandall goes on to identify regional differences as well as the amount of education parents have and its relativity to their opinions of corporal punishment practices. She states the following:

There are big regional differences in spanking. Among Southerners, 62 percent of parents spank their kids; that drops to 41 percent in the rest of the country. Similarly, 73 percent of Southerners approve of spanking children, compared to 60 percent elsewhere.

Even in the South, though, just 35 percent think spanking should be allowed in the schools. Support for spanking in the schools is about the same, 31 percent, in the Midwest, falling to 19 percent in the West and 13 percent in the East. One other difference in spanking is among education groups. Among parents with college degrees, just 38 percent spank their kids; among less-educated parents, it's 55 percent.

What we can take away from this data is that throughout the United States there is a unified concern and disagreement with corporal punishment practices within schools. With this said we return to our initial question of "What is the purpose of corporal punishment and why do we still use this discipline technique?"

The data we have presented as well as the opinions of the American public all steer toward the removal of corporal punishment from our schools, but what is the hold up? Why do we still allow this practice to go on? It seems there may need to be more vocalization from Americans regarding this topic in order to get the proverbial ball rolling.

There is another poll that was administered by Harris Interactive Polling which will also shed some light on how Americans view corporal punishment. This poll is more recent, it was administered in 2013. Harris Interactive Polling also administered the same poll in 2005 and that data is also provided. The table 
at the reveals what questions was included in the poll, in which Harris Interactive Polling asked "Do you think parents spanking their children is sometimes appropriate or is never appropriate?", as well as the results seen in Table 1.

Note: Percentages may not add up to $100 \%$ due to rounding; 1995 data was collected by telephone.

The Harris Poll@ \#67, September 26, 2013

By Regina A. Corso, SVP, Harris Poll and Public Relations, Harris Interactive[5]

The Harris poll shows a trend over time that people are becoming less and less likely to support corporal punishment. By using the data in the table a conclusion can also be drawn that there is a generational trend. Of the four generational subsets in the poll, the youngest generation, known as Echo Boomers, displayed the most opposition toward corporal punishment. As each generation increased in age so did the increase in their tolerance and favoritism of corporal punishment. The Harris poll did conflict with the results from the poll administered by Crandall and $\mathrm{ABC}$ News. One difference in the methodology of the polls is that the Harris Interactive poll questioned 2,286 adults and the ABC News poll only questioned 1,015 adults. Another difference is that the Harris poll was administered electronically via the internet and the ABC News Poll was administered by phone. Conclusions can possibly be drawn that due to the fact that the Harris poll had more than double the respondents than the $\mathrm{ABC}$ News poll did and that the Harris poll sought out its respondents via the internet rather than by phone, the Harris poll is a more accurate representation of data.

\section{Analysing research data}

After reviewing data sets, expert opinions, and Americans' opinions it is clear and irrefutable that corporal punishment practices in schools need to be abolished. According to data and opinions collected and reviewed we are in the midst of the disappearance of corporal punishment practices in schools. There is a growing trend taking place in the United States that illustrates a generational change. This generational change consists of younger generations becoming more and more against the use of corporal punishment. There is also data that states the majority of Americans do not feel corporal punishment is a justifiable practice in our schools. This majority stays the same through each geographical region of the United States. With this growing trend we should see corporal punishment decrease and eventually removed from our school system.

This literature review has focused on two types of behavior interventions: School-wide Positive
Interventions and Supports, and corporal punishment in schools. The review has utilized data and opinion on each intervention in order to prove the acceptable use of each intervention. As for the School-wide Positive Interventions and Supports intervention, data and expert opinion support the implementation of this in all schools and all grade levels. There is data that specifically highlights the success and positive results of the intervention implementation. On the other hand, data and expert opinion were used to refute the use of corporal punishment in schools. All of the research and opinion used in this review support the conclusion that corporal punishment has negative consequences for children and youth. It is important to take away two concepts which have attempted to be proven through this literature review. The first concept is that School-wide Positive Behavior Interventions and Supports implementation in schools provides positive results across the school community. The second concept to take away from this literature review is that the practice of corporal punishment in schools is highly detrimental to our nation's children. It is considered to be a human rights violation and a major national violence issue. The facts, data, and opinions in this literature review are meant to provide the reader with the proper tools to make come to an educated conclusion regarding the issues of corporal punishment in schools and the effectiveness of School-wide Positive Behavior Interventions and Supports.

\section{References}

[1] Barrett S., Eber L., \& Weist (2007). Advancing Education Effectiveness: Interconnecting School Mental Health and School-wide Positive Behavior Support.

[2] Beal, K. (2014, March 22). UL Education students decline, more educators leave profession.

Blum, R. MD, MPH, PhD (2005). Best Practices: Building Blocks for Enhancing School Environment.

[3] Bryk, A.S., \& Driscoll, M.E. (1988). The high school as community: Contextual influences and consequences for students and teachers. . Madison, WI. National Center on Effective Secondary Schools

[4] Cohen, J. (2009). School boards and school climate: Where are we now and where do we need to go? Retrieved from: http://www.nsba.org/BoardLeadership/ Governance/KeyWork/Climate-Resources/school-boardsand-school-climate.pdf

[5] Corso, R.A. (2013). Four in Five Americans Believe Parents Spanking Their Children is Sometimes Appropriate: Almost nine in ten U.S. adults were spanked as a child; two-thirds of parents have spanked their child. Retrieved from http://www.harrisinteractive.com/ NewsRoom/HarrisPolls/tabid/447/ctl/ReadCustom\%20Def ault/mid/1508/ArticleId/1283/Default.aspx 
[6] Crandall, J. (2002). Poll: Most Approve of Spanking Kids: Spanking has its place, most

Americans say - but not in school. Retrieved from http://abcnews.go.com/US/story?id=90406

[7] Dupper, D. R., \& Dingus, A. E. (2008). Corporal punishment in U.S. public schools: A continuing challenge for school social workers. Children \& Schools, 30(4), 243250 .

[8] Ferraro, P., \& Weinreich, R. (2006). Unprotected in the classroom: The good news in that corporal punishment is declining in the U.S schools...the bad news is that it's still allowed in 23 states. American School Board Journal, 4142.

[9] Garrison, T. (2001). From parent to protector: The history of corporal punishment in American public schools.

[10] Corporal Punishment in Public Schools, 16, 117.

[11] Greydanus, D.E. (2010). Corporal Punishment in Schools and its Effect on Academic Success. Retrieved from

http://edworkforce.house.gov/uploadedfiles/04.15.10_grey dandus.pdf

[12] Ingraham v. Wright, 430 U.S. 651 (1977). Retrieved from

http://caselaw.lp.findlaw.com/scripts/getcase.pl?court=US $\&$ vol $=430 \&$ invol $=651$

[13] Insel, P.M., \& Moos, R.H. (1974). Health and the social environment. University of Michigan: Lexington Books.

[14] Leithwood K., Seashore Louis K., Anderson S., \& Wahlstrom K. (2004). How Leadership

Influences Student Learning. Retrieved from http://www.wallacefoundation.org/knowledgecenter/school-leadership/key-research/Documents/HowLeadership-influences-Student-Learning.pdf

[15] Murray, J. Becoming a teacher educator: Guidelines for the induction of newly appointed lecturers in initial teacher education [PDF document]. Retrieved online from http://escalate.ac.uk/downloads/7283.pdf

[16] Ninan, M. (2006). School climate and its impact on school effectiveness: a case study [PDF]. Retrieved online from ttp://www.leadership.fau.edu/ icsei2006/Papers/Ninan.pdf

[17] Patall, E. A., Cooper, H., \& Wynn, S. (2010).The effectiveness and relative importance of choice in the classroom.

[18] Journal of Educational Psychology Arthur Graesser (Eds.),Vol 102 (4) 896-915. American Psychological Association.

[19] Sandberg, A. (2007). School climate and faculty relationships [PDF]. Retrieved online from http://www.schoolclimate.org/climate/documents/GangiTr acydissertation 10-20-09.pdf
[20] Society for Adolescent Medicine, Ad Hoc Corporal Punishment Committee (2003). Corporal punishment in schools: Position Paper of the Society for Adolescent Medicine. Journal of Adolescent Health, 32, 385-393.

[21] Tschannen-Moran, M. \& McMaster, P. (2009). Sources of self-efficacy: Four professional development formats and their relationship to self-efficacy and implementation of a new teaching strategy. Elementary School Journal, 110, 228-248.

[22] Parsons, B. (2014). Whipping Boys: Attitudes Towards Beating in Medieval Pedagogy. Educational Journal, Issue 191, 10-11. 